\title{
SUBSTANSI MODUL KONSELING SEBAYA DALAM MENGATASI PERMASALAHAN KESEHATAN REPRODUKSI PADA REMAJA AKHIR
}

\author{
Ismiyati $^{1}$, Deni K.Sunjaya ${ }^{2}$, Susi Susanah $^{3}$ \\ ${ }^{1}$ Jurusan Kebidanan Poltekkes Kemenkes Banten \\ ${ }^{2}$ Departemen Ilmu Kesehatan Masyarakat Fakultas Kedokteran Universitas Padjadjaran \\ ${ }^{3}$ Departemen Ilmu Kesehatan Anak Fakultas Kedokteran Universitas Padjadjaran
}

\begin{abstract}
ABSTRAK
Perilaku seks pranikah pada remaja cukup tinggi. Hal tersebut didasari dari gaya berpacaran yang tidak sehat sehingga dapat melakukan hubungan seks pranikah. Perilaku seks pranikah pada remaja memiliki risiko terhadap kehamilan yang tidak diinginkan. Hasil SKDI 2012 menunjukkan 10\% remaja wanita umur 15-19 tahun sudah menjadi ibu, 7\% remaja pernah melahirkan, dan 3\% sedang hamil anak pertama. Desain penelitian yang digunakan adalah metode kualitatif. Informan penelitian kualitatif berjumlah 11 orang. Penelitian dilakukan di Provinsi Banten pada bulan Januari-Juni 2017. Pada saat memberikan konseling seorang konselor harus memahami tentang materi ataupun substansi yang dikonselingkan. Hal ini dibutuhkan untuk memberikan informasi kekonseli. Informasi yang tepat akan membantu konseli menyelesaikan masalahnya. Konseling sebaya pada remaja membutuhkan modul. Substansi yang harus ada dalam modul pada penelitian ini diantaranya adalah tumbuh kembang remaja, kesehatan reproduksi, penyakit seksual, keluarga berencana, dan napza. Substansi tersebut digunakan untuk membantu mengatasi permasalahan yang dialami remaja berkaitan dengan kesehatan remaja.
\end{abstract}

Kata Kunci: Substansi Modul Konseling Sebaya, Kesehatan Reproduksi Remaja

Korespondensi: Ismiyati. E-mail: itayimsi@yahoo.co.id

\section{PENDAHULUAN}

Permasalahan remaja saat ini dipengaruhi oleh gaya berpacaran yang tidak sehat sehingga dapat melakukan hubungan seks pranikah. Hubungan seks pranikah yang terjadi pada remaja disebabkan oleh rasa penasaran/ingin tahu $(57,5 \%$ laki-laki $)$, terjadi begitu saja (38\% perempuan), dan dipaksa oleh pasangan (12,6\% perempuan). Hal tersebut mencerminkan kurangnya pemahaman remaja tentang risiko hubungan seksual dan kemampuan untuk menolak hubungan yang tidak mereka inginkan. (Kemenkes, 2015)

Umaroh et all (2016) menyatakan bahwa perilaku seksual pranikah pada remaja dipengaruhi oleh gaya hidup berisiko. Gaya hidup berisiko yang dimaksudkan adalah merokok, minum minuman beralkohol, dan menggunakan obat terlarang (narkotika/napza). Hasil Survei Demografi Kesehatan Indonesia (SDKI) pada tahun 2012 tercatat bahwa remaja perempuan yang merokok $10 \%$ dan minum-minuman 
beralkohol 5\%. Persentase remaja laki-laki yang merokok $80 \%$ dan minum-minuman beralkohol $40 \%$. Remaja perempuan yang menggunakan obat-obatan terlarang sekitar $1 \%$ dan remaja laki-laki $4 \%$.

Perilaku seks pranikah pada remaja memiliki risiko terhadap kehamilan yang tidak diinginkan. Kehamilan yang terjadi dapat berlanjut pada aborsi yang tidak aman dan pernikahan remaja. Hasil SKDI 2012 menunjukkan $10 \%$ remaja wanita umur 15-19 tahun sudah menjadi ibu, 7\% remaja pernah melahirkan, dan 3\% sedang hamil anak pertama. Kehamilan pada usia remaja (muda) memiliki risiko terjadinya anemia, hipertensi, eklamsi, kelahiran prematur, berat badan lahir rendah (BBLR), infeksi, dan perdarahan persalinan yang dapat meningkatkan kematian ibu dan bayi. Penularan penyakit menular seksual juga menjadi risiko tinggi pada perilaku seks pranikah. Prevalensi Infeksi Menular Seksual (IMS) tertinggi terjadi pada wanita belum menikah (24\%) dan remaja perempuan umur 15-19 tahun (19\%).(Kemenkes, 2015)

Upaya Pemerintah untuk mengatasi permasalahan remaja menggunakan pendekatan teman sebaya melalui Program Pusat Informasi dan Konseling Remaja/Mahasiswa (PIK R/M). Menurut Abdi $F$ et all (2013) bahwa teman sebaya memiliki peran penting dalam perkembangan psikososial remaja. Remaja berpendapat bahwa teman sebaya lebih dapat memenuhi kebutuhan dan menerima perbedaan pendapat dari pada orang dewasa. Namun, untuk melakukan konseling sebaya tersebut dibutuhkan substansi untuk membantu mengatasi permasalahan yang ada.

Tujuan penelitian ini adalah untuk mengetahui kebutuhan substansi modul konseling sebaya dalam membantu megatasi masalah yang berkaitan dengan kesehatan reproduksi.

\section{METODE}

Desain penelitian yang digunakan adalah metode kualitatif. Data kualitatif diambil dengan metode wawancara mendalam menggunakan instrumen pedoman wawancara yang dibuat oleh peneliti. Informan penelitian kualitatif berjumlah 11 orang. Informan dalam penelitian ini adalah pengguna layanan konseling sebaya (konselor dan konseli), tenaga kesehatan (dokter obgyn, dokter anak, dan bidan) yang memberikan layanan kesehatan reproduksi dan keluarga berencana, psikolog yang memberikan layanan konseling remaja, BKKBN, Dinas Kesehatan, dan Pembina Pusat Informasi dan Konseling Mahasiswa. Data kualitatif dianalisis secara konten oleh peneliti. Penelitian dilakukan di Provinsi Banten pada bulan Januari-Juni 2017. Penelitian ini telah mendapatkan izin kelayakan dari komisi etik penelitian kesehatan Fakultas Kedokteran Universitas Padjadjaran dengan Nomor Surat 
Persetujuan

Etik:

47/UN6.C1.3.2/KEPK/PN/2017

HASIL

Pada saat memberikan konseling seorang konselor harus memahami tentang materi ataupun substansi yang dikonselingkan. Hal ini dibutuhkan untuk memberikan informasi kekonseli. Informasi yang tepat akan membantu konseli menyelesaikan masalahnya. Berdasarkan pernyataan responden pada wawancara mendalam dan FGD, untuk memberikan konseling kesehatan reproduksi pada remaja akhir yang ada di Provinsi Banten, maka seorang konselor perlu mengetahui substansisubstansi sebagai berikut:

\section{a. Tumbuh Kembang}

Masa remaja adalah masa peralihan dari anak-anak ke dewasa. Pada masa remaja terjadi pertumbuhan dan perkembangan yang cepat. Modul ini digunakan untuk remaja akhir, namun materi tumbuh kembang tetap dibutuhkan. Konselor harus memahami materi tentang tumbuh kembang remaja secara fisik maupun psikologis. Tumbuh kembang diberikan kepada meraka supaya remaja memahami perubahan yang terjadi di dalam dirinya. Mereka dapat mendeteksi kelainan yang mungkin ada di dalam tubuhnya. Deteksi secara dini akan membantu proses pengambilan tindakan secara tepat.

\section{b. Keluarga Berencana}

Pengenalan keluarga berencana perlu dikenalkan kepada remaja untuk perencanaan pernikahan dan keturunan. Adanya perencanaan keluarga pada remaja akan membantu mereka menjalani kehidupan yang sejahtera.

Keluarga Berencana yang dikenalkan kepada remaja meliputi:

1) Pendewasaan Usia Perkawinan

Remaja perlu mengerti tentang pendewasaan usia perkawinan yang membahas batasan usia ideal menikah. Pernikahan yang dilakukan pada usia matur akan memiliki manfaat terhadap kesehatan dan kesejahteraannya. Pendewasaan usia perkawinan pada remaja berisi tentang persiapan pranikah seperti pemeriksaaan kesehatan, persiapan gizi, serta melakukan imunisasi.

"ajarkan supaya dia tidak menikah dini, kan bahaya untuk kesehatan dan ekonominya kelak" (R2)

\section{2) Fungsi Keluarga}

Keluarga berencana juga mengajarkan tentang fungsi keluarga kepada remaja. Pada fungsi keluarga terdapat normanorma yang diterapkan dalam keluarga. Fungsi keluarga yang diajarkan sesuai 
kurikulum BKKBN tahun 2014 adalah fungsi agama, sosial budaya, cinta dan kasih sayang, perlindungan, reproduksi, sosialisasi dan pendidikan, ekonomi, dan lingkungan.

“....diajarkan 8 fungsi keluarga sesuai kurikulum sebelumnya"(R8)

3) Kontrasepsi

Pengenalan kontrasepsi kepada remaja pada keluarga berencana bertujuan untuk membantu meningkatkan pemahaman/pengetahuan remaja. Pengetahuan yang benar tentang kontrasepsi membantu mengatasi permasalahan remaja. Kontrasepsi yang diperlukan untuk konseling kepada remaja berdasarkan pernyataan responden diantaranya mereka harus tahu tujuan kontrasepsi, jenis kontrasepsi, cara kerja kontrasepsi, cara pemakaian, efek samping, efektifitas, keuntungan dan kerugian.

"Kalau untuk informasi sih kita menjelaskan sejelas-jelasnya, mulai dari apa itu alat kontrasepsi, tujuannya untuk apa, efek samping yang ditimbulkan, cara kerja...." (R7)

Mereka juga perlu mengetahui siapa saja yang dapat menggunakan kontrasepsi berdasarkan kondisi kesehatannya. Seleksi klien ini dibutuhkan pada layanan kesehatan sebagai bentuk penapisan awal. Pengenalan seleksi klien pada kontrasepsi untuk remaja sebagai pengetahuan mereka terkait ketepatan jenis kontrasepsi berasarkan kondisi kesehatan pengguna. "KB yang paling memungkinkan. dalam arti kita mesti lihat dia apakah di pil, di spiral, apakah di susuk, tetapikan ada beberapa yang infasif" (RI)

Remaja perlu mengetahui fungsi kontrasepsi sebagai perlindungan ganda. Salah satu jenis kontrasepsi memiliki fungsi melindungi terjadinya kehamilan dan tertularnya penyakit seksual. Informasi ini wajib diberikan kepada remaja yang seksual aktif (seks bebas) sehingga membantu mengurangi permasalahan remaja terkait kehamilan remaja, persalinan remaja, dan penyakit seksual seperti IMS serta HIV/AIDS.

"mereka mungkin tidak tahu bahwa kondom itu bisa mencegah kehamilan dan infeksi menular seksual ketika melakukan hubungan sexual" (R6)

Kontrasepsi darurat juga dikenalkan kepada remaja agar mereka mendapatkan informasi yang dapat dipertanggung jawabkan sebagai bentuk pengetahuan. Mereka perlu tahu jenis kontrasepsi darurat, cara kerja, dan waktu penggunaan kontrasepsi darurat. Pengenalan kontrasepsi darurat ini sangat bermanfaat bagi mereka yang memiliki kasus tertentu seperti perkosaan serta remaja seksual aktif yang tidak 
menggunakan alat kontrasepsi sebelumnya.

"Sekarang itu era elektronik ya.. Walaupun kita tidak kasih tau pasti dia akan mencarikan. Makanya untuk pengetahuan kondar sebaiknya diberi tahu gitu.. untuk pengetahuannya." (R11)

\section{c. Kesehatan Reproduksi}

Usia remaja merupakan usia mulai berfungsinya alat-alat reproduksi tetapi belum matur. Kesehatan reproduksi yang dikenalkan kepada remaja berkaitan dengan seksualitas. Mereka perlu tahu organ reproduksi baik organ luar maupun dalam, masa pubertas yang ditandai dengan proses menstruasi, konsepsi, kehamilan, serta kelahiran. Remaja juga perlu tahu tentang risiko dari perilaku seks bebas terhadap kesehatan reproduksinya. Seks bebas dapat mengakibatkan terjadinya kehamilan tidak dikehendaki yang berlanjut dengan aborsi pada remaja.

"hubungan seksual diluar nikah itu bisa terjadi kehamilan yang tidak diinginkan, resikonya akan berakibat fatal terhadap kesehatan reproduksi serta hati-hati aborsi" (R7)

\section{d. Penyakit seksual}

Penyakit seksual seperti IMS dan HIV/AIDS dikenalkan kepada remaja akibat dari perilaku seks bebas. Kasus penyakit seksual masih menjadi permasalahan bagi remaja di Provinsi Banten. Penyakit seksual yang diderita akan mengganggu sistem reproduksi. Penularan penyakit seksual ini memiliki dampak pada keturunannya bila terjadi kehamilan. Remaja perlu dibekali tanda dan gejala untuk mengetahui atau mendeteksi secara dini penyakit seksual. Proses penularan dan pencegahan diberikan supaya mereka berusaha untuk tidak tertular atau mencegah penyakit seksual.

"Penyakit menular seksual misal dia kena AIDS atau HIV nya positif, itu bisa menularkan kepada anak yang sehat. Sehingga ibunya atau anak itu misalkan remaja laki-laki atau perempuan terus dia berumah tangga atau dia melakukan hubungan seksual dengan pasangannya dan pasangannya itu hamil maka akan berakibat kepada sistem reproduksi atau pun pada anak yang dilahirkan" (R7)

\section{e. Napza}

Napza merupakan salah satu permasalahan remaja yang ada di Provinsi Banten. Penggunaan Napza jenis narkotika dengan suntikan secara bersama-sama berisiko untuk menularkan HIV/AIDS. Tujuan dikenalkannya Napza kepada remaja supaya mereka mengetahui bahaya dan risiko penggunaan Napza. Hal tersebut harapannya untuk meningkatkan 
pengetahuan mereka sehingga mereka dapat menghindarinya.

"dari awal kita kasih tau bahwa napza itu adalah hal yang negatif, hal yang tidak baik untuk dilakukan” (R2)

\section{PEMBAHASAN}

Remaja merupakan masa perkembangan yang unik. Pertumbuhan dan perkembangan pada remaja adalah proses yang berkelanjutan dan membawa perubahan. Pada masa ini perubahan fisik dan psikologi perlu dikenalkan kepada remaja. Sawyer SM dkk menyatakan bahwa terjadi perubahan perkembangan yang berbeda pada kelompok remaja baik remaja dini (Erly adolescence), remaja akhir (late adolescence), maupun pada usia anak muda (young adulthood). Perkembangan ini terjadi pada fisik, kognitif, sosial, dan emosional. (Sawyer SM, 2012)

Pada masa perkembangan ini, terjadi perubahan kompleks yang dipengaruhi oleh faktor hormonal, genetik, dan lingkungan. Hal ini disertai dengan kemampuan kognitif, perkembangan identitas, dan transisi sosial remaja dalam mencapai status dewasa. Perkembangan yang terjadi pada masa remaja tidak semuanya dapat berjalan secara normal. Kelainan perkembangan juga dapat dialami pada beberapa remaja. (Chulani VL, 2014)

Selain tumbuh kembang remaja, kesehatan reproduksi merupakan substansi terpenting dalam membantu mengatasi permasalahan yang ada pada remaja diantaranya seks bebas. Seks bebas pada remaja ini menjadi tantangan global yang dapat menyebabkan permasalahan baru. Permasalahan tersebut diantaranya kehamilan remaja, aborsi, maupun penyakit seksual seperti infeksi menular seksual (IMS) dan HIV/AIDS pada remaja. (Morris JL, 2015)

Semua remaja perlu mendapatkan konseling antisipatif dan berkelanjutan. Konseling yang diberikan tentang fungsi serta kerja organ reproduksi yang sudah matur, proses menstruasi dan masa subur, proses terjadinya kehamilan, perilaku seksual berisiko, dan pencegahan IMS atau HIV/AIDS. Pada remaja yang sudah aktif secara seksual perlu mendapatkan konseling kontrasepsi, Jenis IMS (klamidia dan gonore), dan tes HIV serta IMS sebagai indikasi medis.(Ralph LJ, 2010. WHO, 2010. Bkkbn,2014)

Pada studi yang dilakukan oleh Ismiyati dkk didapatkan bahwa adanya pro dan kontra dalam mengenalkan kontrasepsi pada remaja di Provinsi Banten. Pada kelompok yang sepakat untuk mengenalkan kontrasepsi, terdapat beberapa alasan yang dapat dipertimbangkan. Alasan tersebut diantaranya adalah remaja mulai memiliki perkembangan pemahaman sehingga dapat membedakan hal baik maupun buruk dan pola pergaulan bebas pada remaja zaman sekarang sehingga menimbulkan permasalahan seks pranikah. Kontrasepsi merupakan bagian dari keluarga berencana. 
Pada penelitian ini, kontrasepsi merupakan substansi yang perlu dimasukkan kedalam modul konseling sebaya.

Substansi keluarga berencana pada penelitian ini juga mencakup tentang pendewasaan usia perkawinan (PUP) dan fungsi keluarga. Substansi PUP dapat membantu mengurangi permasalahan pada pernikahan dini, sedangkan fungsi keluarga dapat membentuk perkembangan perilaku emosional dan sosial anak.

Kebutuhan substansi tentang keluarga berencana pada penelitin ini didukung dengan hasil penelitian Ismiyati et all (2017). Hasil penelitiannya di dapatkan bahwa substansi pendewasaan usia pernikahan (PUP), fungsi keluarga, dan kontrasepsi dibutuhkan oleh konseli dan konselor remaja. Pada materi PUP merupakan materi yang sangat dibutuhkan oleh mereka.

Pengenalan keluarga berencana secara dini pada remaja akan membantu memberdayakan remaja perempuan mempunyai kontrol diri terhadap keputusan reproduksinya. Keluarga berencana mendukung hak anak perempuan untuk merencanakan pernikahan dan memiliki anak sampai dia siap secara fisik, psikologis, dan ekonomi. Mereka akan mampu membuat perencanaan untuk kehidupannya saat menikah dalam menentukan jumlah anak yang diinginkan. Keluarga berencana pada remaja dengan seksual aktif akan membantu menghindari kehamilan yang tidak diinginkan dan komplikasinya.(WHO,2016 \& Starbird E, 2016)

Salah satu permasalahan yang dihadapi remaja adalah penggunaan obat-obat terlarang. Remaja dikenalkan tentang bahaya narkoba sejak dini. Hal ini penting dilakukan karena studi yang didapatkan oleh Saleh dkk menyatakan bahwa remaja sudah mulai menyalahgunakan NAPZA sejak dibangku SMP.(Saleh HD, 2014) Pada penelitian ini, untuk membantu mengatasi permasalahan remaja tentang penggunaan obat-obat terlarang maka dibutuhkan substansi napza (Narkotika, Psikotropika, dan Zat Adiktif) pada modul konseling. Pada studi Rongione dkk menyatakan bahwa konseling tentang penyalahgunaan narkoba dapat membantu mengurangi penggunaan. (Rongione D, 2011)

Substansi Napza menjadi bagian yang diperlukan untuk membantu mengatasi permasalahan kesehatan reproduksi pada remaja. Menurut Hops et all (2011) menyatakan bahwa remaja yang menyalahgunakan obat-obat terlarang lebih cenderung terlibat dalam perilaku seksual berisiko. Perilaku tersebut berisiko tinggi untuk terkena HIV/AIDS.

\section{SIMPULAN}

Pendekatan konseling tentang kesehatan reproduksi dan seksual yang komprehensif perlu diberikan kepada remaja. Konseling sebaya pada remaja membutuhkan modul. Substansi yang harus ada dalam modul pada 
penelitian ini diantaranya adalah tumbuh kembang remaja, kesehatan reproduksi, penyakit seksual, keluarga berencana, dan napza.

\section{DAFTAR PUSTAKA}

Kemenkes. Pusat data dan informasi: situasi kesehatan reproduksi remaja. 2015

Umaroh AK, Kusumawati Y, Kasjono HS. Hubungan antara faktor internal dan faktor eksternal dengan perilaku seksual pranikah remaja di Indonesia. Jurnal Kesehatan Masyarakat Andalas. 2016; 10 (1): 65-75

BPS, BkkbN, Kemenkes. Survey demografi kesehatan Indonesia: kesehatan reproduksi remaja. Jakarta. 2012

Abdi F, Simbar M. The peer education approach in adolescents: narrative review article. Iranian J Publ Health. 2013; 42 (11): 1200-6

Sawyer SM, Afifi RA, Bearinger LH, Blakemore SJ, Dick B, Ezeh AC, dkk. Adolescance: a foundation for future health. Lancet: 2012;379:1630-40. DOI:10.1016/S01406736(12)60072-5

Chulani VL, Gordon LP. Adolescant growth and development. Prim Care Clin Office Pract 41 (2014) 465-487 http://dx.doi.org/10.1016/j.pop.2014.0 5.002

Morris JL, Rushwan H. Adolescent sexual and reproductive health: The global challenges. International Journal of Gynecology and Obstetrics 131 (2015)
S40-S42.

doi.org/10.1016/j.ijgo.2015.02.006)

Ralph LJ, Brindis CD. Access to reproductive healthcare for adolescents: establishing healthy behaviors at a critical juncture in the lifecourse. Curr Opin Obstet Gynecol. 2010; 22: 369-74

WHO. Developing sexual health programmes. Geneva. 2010

BkkbN. Kurikulum diklat teknis pengelolaan PIK M/R. Jakarta. 2014

Ismiyati, Sunjaya DK, Susanah S, Husin F, Wahmurti T, Sabarudin S. Kebutuhan keluarga berencana pada remaja akhir di provinsi Banten. Konferensi: Pertemuan Ilmiah Tahunan "Inovasi Bidang Kesehatan untuk Peningkatan Kualitas Hidup Manusia. Program Pasca Sarjana Fakultas Kedokteran UNPAD Bandung. 2017;1: 222-26

WHO. Indonesia and Family Planning: An overview. Geneva. 2016;1-8

Starbird E, Norton M, Marcus R. Investing in family planning: key to achieving the sustainable development goals. Global Health: Science and Practice. 2016; 4 (2): 191-210

Saleh HD, Rokhmah D, Nafikadini I. Fenomena Penyalahgunaan NAPZA Di Kalangan Remaja Ditinjau Dari Teori Interaksionisme Simbolik Di Kabupaten Jember. Jurnal Pustaka Kesehatan, vol. 2 (no. 3), September 2014.hlm:468-75 
Rongione D, Erford BT, Broglie C. Alcohol and Other Drug Abuse Counseling Outcomes for School-Aged Youth $A$ Meta-Analysis of Studies From 1990 to 2009. Couns Outcome Res Eval. 2011. doi.org/10.1177/2150137811400595

Hops H, Ozechowski TJ, Waldron HB, Devis B, Turner CW, Brody JL, Barrera M. Adolescent Health-Risk Sexual Behaviors: Effects of a Drug Abuse Intervention. AIDS Behav. 2011 November ; 15(8): 1664-1676. doi:10.1007/s10461-011-0019-7 